\title{
Can Bank Supervisors Rely on Market Data? A Critical Assessment from a Swiss Perspective
}

\author{
Urs W. Birchler* and Matteo Facchinetti**
}

JEL-Classification: G14, G21, G28

Keywords: Market Discipline, Banking Supervision, Switzerland

\section{Introduction}

Banking supervision has become more difficult in the course of internationalization, financial innovation and concentration in the banking industry. Particularly the bigger, internationally active banks are financially, legally, and organizationally complex institutions. Timely identification of problems at individual banks and of disequilibria building up in the banking system has become a daunting task.

A crucial factor in these developments is the market. Markets play an ambiguous role. On the one hand, financial markets are a driving force behind the increasing complexity of banks: They offer an unprecedented choice of sophisticated instruments to manage, diversify, but also to conceal risks. On the other hand, markets may facilitate the tasks of supervisors in two ways. First, markets exert direct market discipline: Risky banks may find it difficult or expensive to refinance. Second, for bank supervisors market data may be a source of indirect discipline: The terms at which banks borrow may reveal to supervisors valuable information on investors' perception of bank quality.

Indeed, it is well known that markets process and aggregate information available to investors. HaYeK (1945), in his classic article, defines a society's main

* Swiss National Bank, Börsenstrasse 15, 8022 Zurich; Fax: +41-44-631-81-09; e-mail: urs. birchler@snb.ch.

** Swiss National Bank, Börsenstrasse 15, 8022 Zurich; Fax: +41-44-631-81-09; e-mail: matteo. facchinetti@snb.ch. The opinions expressed in this paper do not necessarily reflect those of the Swiss National Bank or its staff. For helpful comments we are indebted to Jeannette Henggeler-Müller, Pierre Monnin and several other colleagues at the Swiss National Bank, as well as to two anonymous referees. 
economic problem as aggregating "the dispersed bits of incomplete and frequently contradictory knowledge which all the separate individuals possess" (p. 519). And he goes on to claim that "this problem can be solved, and in fact is being solved, by the price system” (p. 525). Hayek's vision has inspired the modern hypothesis of informationally efficient markets, which claims that all available information is reflected in market prices.

If the efficient markets hypothesis is true, observed yields on bank debt and equity reflect the available information on the probability distribution of bank returns. Such market data may not be free of noise, but they are likely to convey valuable signals on bank quality and risk. The reason is that "market participants have an incentive to look through reported accounting figures to the real financial condition of a bank and to price a bank's securities based on their best estimates of the distribution of the security's future cash-flows" (EvanOfF and WALL, 2001, p. 122).

Several studies have examined the information content of market data on bank risk. The international evidence suggests that market signals are indeed informative, especially for banks in industrialized countries. Most evidence exists on the US (see Flannery, 1998, for an overview of the early literature and Krainer and Lopez, 2001; Swidler and Wilcox, 2002; Curry, Elmer and Fissel, 2003; Fan, Haubrich, Ritchken and Thomson, 2003 for more recent research). Recent contributions treat European banks (Persson, 2002; Sironi, 2003; Gropp, Vesala and Vulpes, 2006) or Japanese banks (Brewer, Genay, Hunter and Kaufman, 2003). ${ }^{1}$ Some researchers (see, e.g., Berger, Davies and Flannery, 2000; Evanoff and Wall, 2001; Gunther, Levonian and Moore, 2001; Cannata and Quagliarello, 2005) find that market data are not only informative, but that they also contain information which is not yet part of confidential supervisors' information. At the same time, market data do not reflect all information available to supervisors. ${ }^{2}$ In other words, this branch of the literature suggests that supervisory information and market information are complementary sources of bank supervisory intelligence.

Market prices have been used or proposed as a source of information in different contexts as well. Presidential betting markets like the electronic market run by the University of Iowa have performed very well as predictors of presidential

1 Market signals appear to be less informative in emerging countries, though. See, e.g., BonGINI, Laeven and Majnoni (2002) or Sy (2002).

2 This suggests that markets may be informationally efficient in the so-called semi-strong sense (reflecting all publicly available information) but not necessarily in the strong sense (also reflecting private information available, for instance, to supervisors). 
elections (RHode and STRUMPF, 2004), of the number of books sold on the first day of a Harry Potter release or of the regional incidence of flu ('flu-tures'). ${ }^{3}$ Several internet betting sites quote a number of contracts predicting events from sports and politics; the Hollywood stock exchange predicts the success of movies and movie stars, including awards. In July 2003, the US Department of Defense disclosed a plan to introduce a market for political events. It was argued that "markets are extremely efficient, effective and timely aggregators of dispersed and even hidden information" (Pentagon Prepares a Futures Market on Terror Attacks, New York Times, July 29, 2003). Prices of individual contracts would thus reflect the probabilities of the respective event. The idea of trading in 'terrorist futures', as critics put it, met with political and moral concerns and was abandoned (for details see Wolfers and Zitzewitz, 2004).

Bank supervisors and central banks do not have to create markets first, before deriving information from prices. Market information in the form of data on the yields of bank equity and subordinated debt is available for many banks in a number of countries (BAsel Committee for Banking Supervision, 2003). ${ }^{4}$ Central banks and supervisory authorities are thus confronted with the question: Should observed market prices be taken into account for policy decisions in the area of banking and systemic stability, and, if yes, to what degree and how? One possible if somewhat vague answer was given by the former Chairman of the Federal Reserve Board, Alan Greenspan: "Significant changes in a banking organization's debt spreads, in absolute terms or compared with peer banks, can prompt more intensive monitoring of the institution" (GREENSPAN, 2001).

While supervisors in most countries do not rely much on market information, the issue is on the table. ${ }^{6}$ Some economists even advocate the use of market data, particularly in the form of subordinated debt spreads, as automatic triggers for supervisory action (see, for instance, CALOMIRIS, 1999; for an overview of various subordinated debt proposals see BoARd of Governors of THE Federal

3 Predicting Influenza, The Economist, October 19, 2005, p. 84.

4 Banks that issued subordinated debt represent more than 50 percent of banking assets in the Basel Committee member countries.

5 Chairman Greenspan knew that markets can be wrong. The day his nomination was announced, bond markets had their biggest one-day drop in five years (After Alan, The Economist, October 19, 2005, p. 49).

6 A workshop held at the Bank of England in April 2003 made it clear that several supervisors and central banks were interested in the use of bank specific market information, and that research projects were under way in a number of institutions, including the Swiss National Bank. At the same time, with the given state of knowledge, supervisory authorities seem hesitant to tie any specific action to developments in market prices. 
Reserve System, 1999). The supervisory community has taken a cautious and fairly pragmatic stance. The Basel Committee on Banking Supervision has not issued any official statements on the use of market information specific to banks. However, its new minimum capital recommendations for banks ('Basel II') rely on market discipline as the third of three pillars (BASel Committee for BanKING SUPERvision, 2005). Increased bank transparency is thought to strengthen direct market discipline by investors; in addition, a pricing of bank debt and equity that better reflects risk might also provide better information for national supervisory discipline under the second of the three pillars (national implementation of first pillar capital requirements).

In the absence of international recommendations and practical experience, national authorities have little guidance on how to deal with market data specific to banks in their supervisory and system stability approaches. In Switzerland, the question is particularly relevant, given the country's highly developed and internationalized banking system. As responsibilities are shared, there are several potential beneficiaries of market information.

Responsibility for supervising the solvency of individual banks lies with the Swiss Federal Banking Commission (SFBC). Within the Swiss indirect or twostage supervision process, the SFBC traditionally satisfies its data needs from external auditors' reports. In addition, the SFBC collects some data directly, particularly from the two big banks, UBS and Credit Suisse Group (CSG). Hence, to the SFBC, market data might flag problems not recognized by external auditors or by its own indicators and within rather selective on-site examinations. External auditors themselves might get hints for their work from market prices.

The Swiss National Bank (SNB) is the lender of last resort to the banking system and has an explicit mandate to contribute to systemic stability. Its internal database is oriented towards monetary policy, rather than to solvency issues. Access to the SFBC's information is restricted for privacy reasons. Therefore, market data could give the SNB early warning signals not available from other sources.

Finally, there is a private collective deposit insurance scheme run by the Swiss Bankers Association (SBA). The banking community organized in the SBA is thus interested in the solvency of its individual members, but it has no means to supervise them. Even for the banks, market information may thus be used as a makeshift.

In the present paper we examine the suitability of market data for the assessment of banking and systemic risk by Swiss authorities. In particular we try to close two gaps in the literature: We present and interpret the (limited) empirical evidence on market data as solvency and risk indicators for Swiss banks and 
we discuss the information economic issues raised by a possible use of such data for policy purposes. We find that some important aspects have been largely neglected in previous discussions. This is particularly true for the endogeneity problem discussed in 5.2.3.

The remainder of the paper is structured as follows: First, we look at market prices for passive use, i.e., as a pure source of information. In other words, we discuss the informational content of market prices from a theoretical point of view (section 2), we evaluate potential indicators for bank solvency and risk (section 3) and we examine the availability and quality of the relevant data in Switzerland (section 4). Then, we look at market data for active use, i.e., as a basis for supervisory action. In particular, we discuss options for the practical use of market data and the complications arising in such a context (section 5). Finally we draw conclusions regarding the future use of market prices by authorities (section 6).

\section{The Information Content of Market Prices}

In order to assess data requirements or the quality of available market data, we need a benchmark against which to assess the properties of actual data. The relevant benchmark depends on the intended use of market data. In the present section we assume that the supervisor wants to use market data passively, i.e., purely as an additional source of information.

To understand market prices, we need to know how they are generated. First, investors receive or collect relevant information. Second, the market aggregates individual information into prices. The quality of market data as a mirror of fundamentals thus depends on the accuracy or quality of information as well as on the efficiency of the price mechanism.

\subsection{The Quality of Information}

The quality of individual information is often identified with the accuracy or precision of signals individuals get about the true value of uncertain economic variables. It reflects a number of different factors. Investors get their information from a variety of sources including banks' publications, interviews with bank representatives, analysts' or raters' views, the media, rumours, etc. As far as banks'

7 Information acquisition by individuals is not completely differentiated from information aggregation in the markets, since observations on prices and quantities of trades may feed back into the information acquired by individuals. 
publications are concerned, disclosure requirements may improve information quality, and so may the presence of specialized rating agencies. Yet, informational quality is also endogenous in the sense that it depends on investors' own efforts to gather information. Such efforts depend on the cost of obtaining information (again, disclosure may help) and on the benefits of having it; insured depositors, for instance, may not care about the solvency of their bank.

\subsection{The Efficiency of the Market Mechanism}

The extent to which observed asset prices reflect investors' information is normally called the informational efficiency of markets. Markets are informationally efficient (in a theoretical sense) if market participants take the same decisions after observing prices as they would have done had they actually possessed all existing information (BRUNNermeIer, 2001). ${ }^{8}$ Prices then constitute a 'sufficient statistic' for all available information, absolutely in accordance with Hayek's vision. Informational market efficiency is composed of several elements:

\section{a Market Completeness}

Market completeness in simple terms means that there is at least one asset for each potential state of nature (for a more precise definition, see LENGWILER, 2004). Information about the probability of that state can then flow into each individual price. Incomplete markets cannot absorb all the information in an economy. In practice, there are several reasons for market incompleteness. The cost of operating some markets may prevent the issue or the trading of the securities in question. Some states of nature may not be verifiable. A practical example is the non-existence of a contract on the insolvency of a bank that enjoys a 'too-big-to-fail' guarantee (see 4.3).'

b Strong-form Efficiency of Individual Prices (no Profit Opportunities) Efficiency of prices or of markets as used in the empirical literature is different from informational market efficiency in the theoretical sense. It is normally understood as the absence of systematic profit opportunities. ${ }^{10}$ The relevant

8 The empirical concept of informational market efficiency (strong, semi-strong, weak) often used in the finance literature differs from the theoretical concept of informational efficiency (see below).

9 Although the bank may become insolvent, it will never actually default. This makes insolvency a non-verifiable state on which no contracts can be written.

10 Note that under market incompleteness, markets can be efficient in the empirical sense (leaving no profit opportunities) without being informationally efficient in the theoretical sense (reflecting all information). 
notion here is the strong-form efficiency of prices; indirect market discipline can be expected to be most effective when even private information is fully reflected in prices. Note, however, that in a strong-form efficient market, prices also reflect expected supervisory actions. They thus give supervisors no indication on the fundamentals, such as the probability of bank failure in the absence of supervisory intervention. In this sense, supervisors would ideally prefer markets to be 'almost' efficient (see 5.2.3).

c Irrelevance of Higher-order Uncertainty

A third feature of informationally efficient markets (in the theoretical sense) is that prices reflect information about fundamentals, but not beliefs about beliefs. When investors have reason to bet on average market opinion, rather than on the best information available to them, there is a wedge between the observed price and the fundamental value of an asset. ${ }^{11}$ The observed price may then not reflect the information that really interests supervisors.

$\mathrm{d}$ Absence of Noise in the Data

Noise is the difference between observed price and the price consistent with individuals' information. It varies over time. Such a difference can arise due to frictions in the microstructure of markets. ${ }^{12}$ The relative size of this noise, the noise-to-signal-ratio, depends mostly on the liquidity of markets. Market liquidity is commonly defined as the ability of a security to be promptly converted into cash, without any price discount. Clearly, for securities that are liquid and frequently traded, a large amount of information flows into prices and keeps the difference between the (last) observed price and the informationally correct price small.

\subsection{Practical Criteria for Data Quality}

In practice, neither the quality of individual information nor the informational efficiency of markets is perfect. Supervisors looking for information in the markets therefore need a list of priorities for data quality as well as an understanding of what they can and what they cannot know from market data.

11 This phenomenon arises in the presence of irrationality, but also from interactions between public and private signals (MORRIS and SHIN, 2002).

12 Examples of these frictions are physical handling costs or taxes, risk bearing costs (risk-averse liquidity suppliers), asymmetric information, the strategic behavior of financial intermediaries, borrowing constraints or other short-term concerns leading some informed traders not to bet unlimited amounts on their information; see O'HARA (1995). 
The quality of individual information (the first part of the link between fundamentals and market prices; see 2.1) is not directly observable. Although supervisors can never take its accuracy for granted, they may try to improve investors' information, for instance by setting disclosure requirements. Hence, a first practical criterion for information quality is the transparency of the issuing bank.

The efficiency of the market mechanism (the second part of the link between fundamentals and market prices; see 2.2) has, in practice, stronger and weaker components.

a Market completeness in the strict sense is not necessary for a reasonable assessment of banks' probability of failure. No supervisor needs a price reflecting the probability that a bank will become insolvent on a particular day, say, five years from now. A number of securities with sufficiently phased maturities will therefore give a reasonable time-profile of market expectations. Market incompleteness becomes critical, though, if contingencies relevant for supervisors are not priced. A case in point is state guarantee for banks. Under state guarantee, the price of bank debt reflects the probability that either the bank or the state will repay the debt. The probability of the bank becoming insolvent is not separately priced.

b Empirical market efficiency (absence of profit opportunities) is well approximated in reality. It has been confirmed (only in its semi-strong form, though) by a large number of empirical studies for a wide range of markets, even though some violations have been found (Shleifer, 2000). Still, empirical market efficiency is likely to increase with the presence of a sufficient number of professional, highly skilled market participants who buy, hold, or sell a particular security. With respect to large and complex banking organizations, especially, the ability of investors to map signals (bank disclosures) into fundamentals (bank risk) is no trivial matter nowadays.

c Trading on fundamentals or the irrelevance of higher-order uncertainty is a critical issue, however. Since beliefs are not observable, supervisors cannot distinguish changes in market prices that are driven by changes in fundamentals from mere speculation by average opinion on changes in average opinion, or from irrational exuberance (SHILLER, 2000). A recent example of a deviation of market prices from fundamental values is the internet bubble that burst in 2000. Clearly, some securities are more susceptible to bubbles than others.

$\mathrm{d}$ The absence of noise in prices, or a low noise-to-signal-ratio, is another critical link between information and prices, as there are remarkable differences between banks. Thus, frequency of trading and liquidity, which both reduce 
the noise-to-signal-ratio, will be used as important criteria in assessing the quality of available market indicators (see 3 and 4).

In what follows we will thus focus on the criteria of data quality summarized in Table 1.

Table 1: Criteria for Market Data Quality

\begin{tabular}{ll}
\hline Criterion & Rationale \\
\hline Market completeness & $\begin{array}{l}\text { Are there a sufficient number of risk-sensitive securities for a bank? Do } \\
\text { they reflect investors' perceptions of state contingencies that are rele- } \\
\text { vant to supervisors? }\end{array}$ \\
Information quality & $\begin{array}{l}\text { How transparent is the issuing bank? Is there a sufficient percentage of } \\
\text { highly skilled investors with access to information? }\end{array}$ \\
Trade on fundamentals & $\begin{array}{l}\text { Do investors focus on fundamentals or are there indications that prices } \\
\text { are driven by opinions about opinions? }\end{array}$ \\
Noise-to-signal-ratio & $\begin{array}{l}\text { Are markets sufficiently continuous and liquid? Does noise make the } \\
\text { information extraction unfeasible? }\end{array}$ \\
\hline
\end{tabular}

\section{Solvency and Risk Indicators}

In this section we describe the different solvency and risk indicators that can be found on the financial markets. We present, so to say, the 'buffet' from which supervisors interested in market indicators may help themselves. Such indicators can be classified according to their underlying 'target' - either a single institution or the whole banking/financial system - and according to the asset on which they are based - equity, debt, or other instruments.

Each indicator has its own characteristics and focuses on specific aspects of bank risk profiles. Although different indicators for the same bank appear to be complementary in nature, their functional relations in providing information have not been explored in great detail. We will therefore focus on individual indicators and their specific strengths and weaknesses. 


\subsection{Individual Bank Solvency}

\subsubsection{Equity}

With respect to information extraction purposes the main advantage of equity markets lies in their high liquidity and participation rates. While bonds or options are typically traded among institutional investors like hedge funds, pension funds or assurances, an increasing number of smaller private savers directly invest in the stock market. One the one hand, this may broaden the informational basis of stock prices; on the other, the risk of herd behavior may increase. Yet, the basic problem associated with equity-based indicators is related to the fact that shareholders are potential beneficiaries of substantially positive outcomes but are protected by limited liability in the case of a severe downturn. Because of this nonlinear payoff profile they may have an excessive appetite for risk (DEwatripont and Tirole, 1994). Hence absolute equity prices and returns may give ambiguous signals about the soundness of a bank. For example, the stock price of an almost insolvent bank is expected to rise if its managers enter an extremely risky 'game for resurrection' with negative present value. In addition, one can argue that shares are more susceptible to bubbles than other securities due to their unlimited upward potential and infinite maturity.

Regulators as well as investors are aware of these issues and have therefore tried to refine equity-based indicators. The most widespread approach builds on the idea that equity can be seen as an option on the bank's assets (Merton, 1974). By means of modern option pricing theory one can then calculate the implied market value of the assets and their implied volatility from observed share prices and bank balance sheet data. An indicator of default - the 'distance to default' is then derived by comparing market net worth to the standard deviation of the fluctuations in asset value..$^{13}$ Distance to default is available with relatively high frequency, but it is also very sensitive to assumptions regarding the (unknown) underlying distribution of the value of assets. In general, while the absolute values of the distance to default are difficult to interpret, relative changes over time and comparisons across banks may give a useful signal about the market opinion on a particular institution.

Today, Moody's KMV, a financial service company specialized in modeling default risk, uses a more elaborated version of the Merton structural model to

13 Technically, the distance to default is defined as the following expression (the level of the default point usually being determined by the book value of the liabilities): [market value of assets - default point]/[market value of assets*asset volatility]. 
estimate a measure of default probability for various corporations around the world. ${ }^{14}$ Although the KMV model can be easily applied to banks and similar institutions, the results appear less encouraging than in other sectors. Banks have a balance sheet structure that is very different from other firms and more complex. The possibility of government bailout of banks may further distort the results, although this problem may affect equity less than other instruments.

\subsubsection{Debt}

Some supervisors consider subordinated debt spreads ${ }^{15}$ as the best market indicator currently available. Bond markets are relatively deep and established markets, and prices can be observed on a relatively frequent basis. Moreover, bondholders, unlike shareholders, are exclusively concerned with the downside potential of a bank. Hence their concerns and objectives align with those of the supervisor. Subordinated debt holders are the most vulnerable of all bank creditors, including senior debt holders and depositors, as their claims are the first to absorb losses. For these reasons, they have the strongest incentive to monitor bank activities. The majority of the proposals aimed at improving market discipline thus advocate the mandatory issue of subordinated debt and/or some upper limit to acceptable yield spreads. ${ }^{16}$ Such a policy would face a certain choice between different forms of subordinated bank debt - long or short term; debt with put or call options as these also differ with regard to their information content (FAN, HaUBRICH, Ritchien and Thomson, 2003).

However, debt based indicators also have their drawbacks. First, empirical evidence indicates that bond spread movements have a significant systematic component. ${ }^{17}$ In other words, common factors like the interest rate structure or the risk attitude of investors may influence spreads more than changes in the idiosyncratic risk profile of the reference institution. This complicates the interpretation of spread movements. In order to detect idiosyncratic risk changes, comparisons over time and across banks may be useful. Second, the subordinated debt yield does not directly measure risk perceptions of the sophisticated investors who hold

14 In particular, KMV maps the distance to default into a probability of default using an empirical distribution based on historical data. See Crosbie and BoHN (2002) for a detailed description of the KMV methodology.

15 The debt spread or - more precisely - the debt yield spread is defined as the difference in yield between different types of debt obligations. The spread is usually calculated for a risk free security, so as to reflect what the market charges as premium for potential default.

16 See Board of Governors of the Federal Reserve System (1999) for an overview.

17 See, e.g., Elton, Gruber, Agrawal and Mann (2001). 
such debt, but it also reacts to changes in risk attitudes or perceptions of a wider public (BirChler and HaNCOCK, 2003). Third, in special cases bond spreads may inherit the specific problem of standard equity based indicators, i.e., when a bank is insolvent, even debt holders may benefit from an increase in the risk of bank assets. In such a situation, a narrowing spread may signal a deterioration and not an improvement in the risk profile of that bank. Finally, bond liquidity is often quite poor, especially in secondary markets, and therefore liquidity premiums must be taken into account when comparing spreads (НANCOCK and KWAST, 2001; Evanoff and Wall, 2002). ${ }^{18}$

For this latter reason researchers and regulators usually suggest that spreads be calculated on the basis of issue prices (SirONI, 2001). The weakness of primary market data, however, is their limited availability, especially for those banks that issue infrequently. At the same time, the decision to issue debt has some informational content per se, which is embedded in primary market data (BIRCHLER and HANCOCK, 2003). Thus, information on a bank's risk and return profiles is present not only in prices but also in quantities. For traded instruments, quantities appear to be less risk-sensitive than prices (Demirgüç-Kunt and HuizINGA, 2004). For banks that have few traded instruments outstanding, or none at all, quantities (e.g. amount of uninsured deposits) may, however, provide some information (Birchler and MAECHLER, 2002).

\subsubsection{Derivatives}

A derivative is a financial contract whose value is affected by the value of other underlying variables. Derivatives normally come in the more traditional shape of options on shares or bonds, or in the more recent form of credit derivatives. While, in general, the number and variety of financial securities has increased over the last decades, the market for derivatives has experienced a veritable boom. The Bank for International Settlements (BIS) estimates that the global over-thecounter derivatives market had underlying assets of 285 trillion USD at the end of 2005, compared to 95 trillion in $2000 .^{19}$

Credit derivatives are probably the fastest growing component of this market. In the context of risk analysis, the main advantage of credit derivatives lies in the fact that they reflect very specific risks. For example, it is relatively straightforward to extract accurate information about the solvency of a borrower from a

18 However, a part of the difference between the observed price and the fundamental value may be averaged away if there are several bonds and noise is bond specific.

19 See Bank for International Settlements (2006). 
Figure 1: Senior CDS vs Senior Bond Spread of UBS End of month

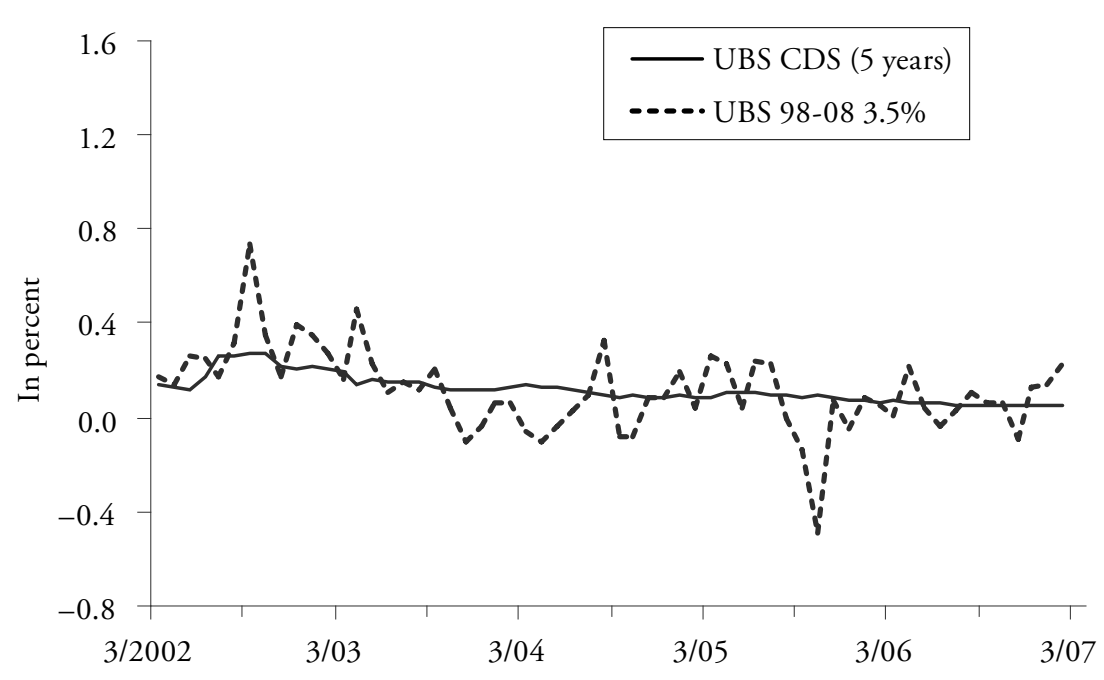

Figure 2: Senior CDS vs Senior Bond Spread of Credit Suisse Group End of month

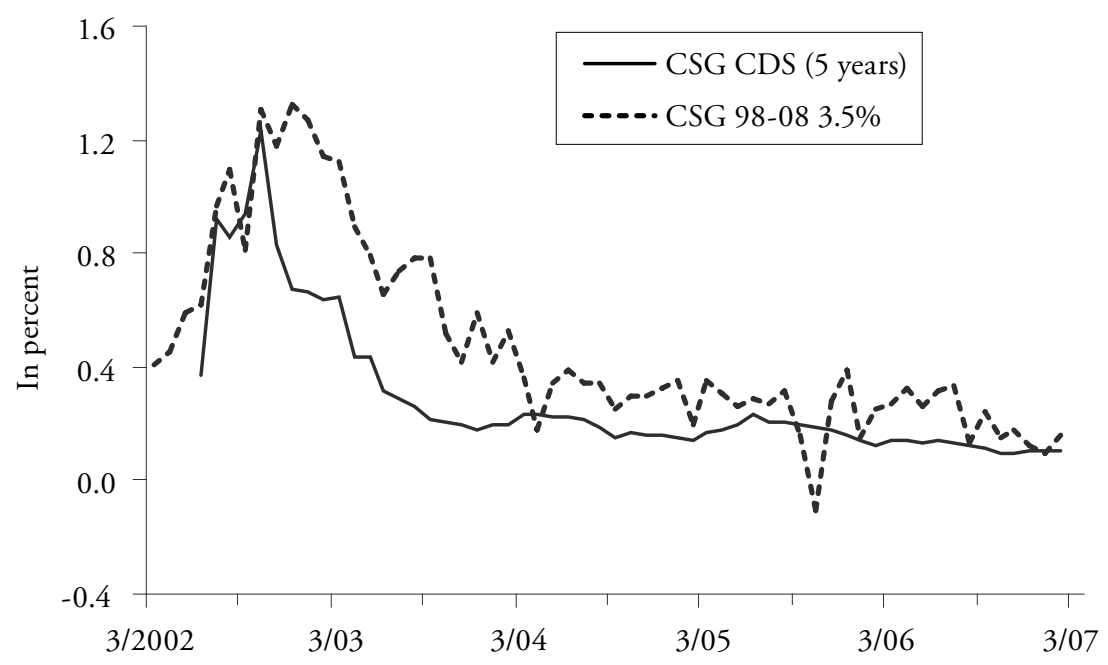

Both Figures: Sources: Bloomberg and Datastream 
credit default option or swap (CDS). For that reason CDSs are becoming increasingly popular as a source of information for supervisors. A CDS is an agreement between two parties, $\mathrm{A}$ and $\mathrm{B}$, in which $\mathrm{A}$ makes $\mathrm{B}$ a fixed periodic payment while $B$ pays A a floating fee that depends on whether a specific credit event relating to a predetermined asset has occurred or not. In other words, a CDS trades exclusively credit risks, and its price is less influenced by other factors than are bond spreads. Moreover, credit derivatives are often more liquid and less noisy than the related spot asset (see Figures 1 and 2). The International Swaps and Derivative Association (ISDA) estimated that the total volume of CDS outstanding reached about USD 26 trillion in June 2006, having doubled annually in the previous five years.

\subsubsection{Ratings}

Information on bank risk does not always need to be extracted from prices or quantities. International agencies like Moody's or Standard and Poor's (S\&P's) specialize in assessing the default risk of a particular institution or security and making the results public in the form of ratings. Public credit ratings are hybrid indicators: They are publicly observable like market prices, but they do not result from a trading process. Since rating agencies normally have access to confidential files of the companies they review, their ratings may indeed represent a useful source of information to supervisors (BASEL COMMITTEE FOR BANKING Supervision, 2000). In addition, the direct revelation of the information has the advantage of disclosing the rationale behind each rating action to supervisors (see 5.2.1).

The 'standard' long term credit ratings have been refined in various ways. The Moody's Bank Financial Strength Ratings (BFSRs) and the FitchIBCA Individual Ratings (FIIs), for instance, are intended to reflect the soundness of a bank without taking credit support from other parties into account. Therefore, BFSRs and FIIs can be especially useful for state owned institutions or for banks that may be considered 'too-big-to-fail' (see 4.3).

One drawback is that rating adjustments often lag the changes in the risk profile of the reference company and therefore can be hardly used as early warning indicators. Some rating agencies also explicitly attempt to rate firms 'through the cycle', thus avoiding rating changes due to cyclical changes in firm solvency (Basel Committee for Banking Supervision, 2000). This may suppress some valuable information on short-term default risk and actual ratings. 


\subsection{Systemic Risk Indicators}

Instead of focusing on a single bank, we can of course use market data to assess the soundness of the whole financial system. The most straightforward way to obtain systemic risk indicators is to aggregate the above measures over bank groups or sectors. There are also some indices (e.g. the Swiss Performance Index, SPI, has a subindex containing only bank shares) and wide-ranging securities available in the market, for which the standard indicators can be directly calculated.

In addition, some researchers have recently developed more complex measures of system risk based (also) on market data. The index of financial stress for Canada (ILling and Liv, 2003), for instance, represents an attempt to develop a composite measure aimed at predicting banking crises. Information about financial stress is extracted exclusively from market data and elaborated, using several techniques. Four markets are included in the computation: banking, foreign exchange, debt and equity. According to its authors, this index outperforms other financial stress measures in identifying periods of tension for the Canadian financial system.

Yet, there seems to be scope for some aggregate measures of systemic pressure, modeled on the Bank of Canada's stress index but also incorporating non-financial price-based information. In particular, the inclusion of real economic data or bank balance sheet data (current figures plus forecasts) might further improve the accuracy of predicting crises. The Swiss National Bank (SNB), within its mandate to oversee systemic stability, has recently developed a stress index based on a broader set of data (Swiss National Bank, 2006; Hanschel and Monnin, 2004, 2005). ${ }^{20}$ This index appears to do a good job in detecting periods of stress for Switzerland (see 4.4).

In a systemic context, market information can be useful also for exploring other more specific issues. By analyzing bank contagion in Europe, Gropp, Lo DuCA and Vesala (2006) show how equity market prices can be used to identify systemically important banks within and across countries. In particular, their indicator helps to detect foreign banks and markets which domestic supervisors should monitor closely because of their close link to the home bank sector. The work of Gropp, Lo Duca and Vesala builds on the Merton model, in that they analyze the correlation and causality structure of extreme shocks affecting the distance to default for a sample of banks.

20 The index combines market data (stock and bond prices), accounting data (interbank deposits, bank profitability, bank capital, bank provisioning rate), supervisory information (number and size of institutions on the regulator's watchlist) and structural features of the Swiss banking system. Macroeconomic indicators are used as proxies for some of the above variables in order to forecast the index. 


\section{The Availability and Quality of Market Data in Switzerland}

In the present section we will examine whether market data are available in sufficient quality for the Swiss banking system. Above (2.3) we have defined data quality as: the availability of securities (with different maturities) that reflect banks' perceived risk profiles; the transparency of the issuing bank or investors' skill and access to information; the dominance of fundamentals over higher-order beliefs in the market; the continuity of trading and the liquidity of markets.

\subsection{Availability}

In Switzerland, market data are available for a minority of banks; however, these banks constitute a major part of the banking system (see Table 2). For the two big banks, in particular, data quality is high, since both UBS and CSG have issued numerous financial instruments for which the market is quite liquid. Market data quality for smaller banks - in particular regional banks and some cantonal banks - is usually inferior, given lower trading volume and investors' interest. The vast majority of Swiss institutions have neither a financial rating nor any outstanding traded securities. Indeed, the data sets for subordinated debt and for equity are small. By the end of 2006, only 7 Swiss banks had quoted subordinated debt outstanding and only 25 banks were listed on a stock exchange. Yet, these banks accounted for 80 percent respectively 84 percent of the total assets of the banking system. Moreover, driven by consolidation of the Swiss banking sector during the real estate crisis of the 90 s and the strong growth of big banks' international operations, the ratio of total assets of banks active in financial markets to total assets of the banking system grew steadily throughout the last decade. As a result, there seem to be sufficient market data for an assessment of systemic stability in the Swiss banking sector. ${ }^{21}$

In the future, the importance of market-based funding is likely to increase, also for smaller institutions. In recent years, many medium-sized and small-sized banks have experienced a reduction in retail-based funding resources (such as savings accounts). Several of them are trying to gain access to the capital markets in order to find the funds needed for their business. Due to their modest size, most of these institutions have had to intensify the collaboration within the respective bank groups in order to gain efficient access to the capital markets. The Raiffeisen

21 For this reason, the Swiss National Bank also uses the principal market indicators described in the text as inputs (among others) when assessing the stability of the banking system. 
Table 2: Summary of the Availability and on the Quality of Market Indicators in Switzerland

\begin{tabular}{|c|c|c|c|c|c|c|c|c|c|}
\hline \multirow[t]{3}{*}{ End of 2006} & \multirow[t]{3}{*}{$\%$ of } & \multicolumn{6}{|c|}{ Available indicators ${ }^{\mathrm{a}}$} & \multirow[b]{3}{*}{$\begin{array}{c}\text { Liquidity and } \\
\text { data quality }\end{array}$} & \multirow[b]{3}{*}{ Other issues ${ }^{\mathrm{b}}$} \\
\hline & & \multicolumn{2}{|c|}{ Debt } & \multirow[t]{2}{*}{ Equity } & \multirow[t]{2}{*}{ CDS } & \multicolumn{2}{|c|}{ Ratings (Moody's, S\&P, Fitch) } & & \\
\hline & & Senior & $\begin{array}{c}\text { Subordi- } \\
\text { nated }\end{array}$ & & & $\begin{array}{l}\text { Long term } \\
\text { credit }\end{array}$ & $\begin{array}{l}\text { Financial } \\
\text { strength }\end{array}$ & & \\
\hline \multirow{2}{*}{ Big banks } & banks & $100 \%$ & $100 \%$ & $100 \%$ & $100 \%$ & $100 \%$ & $100 \%$ & \multirow{2}{*}{ high } & \multirow{2}{*}{ TBTF } \\
\hline & assets & $100 \%$ & $100 \%$ & $100 \%$ & $100 \%$ & $100 \%$ & $100 \%$ & & \\
\hline \multirow{2}{*}{ Cantonal banks } & banks & $71 \%$ & $13 \%$ & $46 \%$ & - & $42 \%$ & $8 \%$ & \multirow{2}{*}{ mixed } & \multirow{2}{*}{$\begin{array}{c}\text { state } \\
\text { guarantee }\end{array}$} \\
\hline & assets & $94 \%$ & $20 \%$ & $50 \%$ & - & $73 \%$ & $33 \%$ & & \\
\hline \multirow{2}{*}{ Regional banks ${ }^{c}$} & banks & $3 \%$ & $1 \%$ & $6 \%$ & - & $1 \%$ & - & \multirow{2}{*}{ medium/ low } & \\
\hline & assets & $25 \%$ & $20 \%$ & $50 \%$ & - & $19 \%$ & - & & \\
\hline \multirow{2}{*}{ Raiffeisen Group } & banks & $100 \%$ & - & - & - & $100 \%$ & $100 \%$ & \multirow{2}{*}{ medium } & \\
\hline & assets & $100 \%$ & - & - & - & $100 \%$ & $100 \%$ & & \\
\hline \multirow{2}{*}{ Other banks } & banks & $2 \%$ & - & $3 \%$ & - & $4 \%$ & $2 \%$ & \multirow{2}{*}{ medium/ low } & \\
\hline & assets & $16 \%$ & - & $12 \%$ & - & $32 \%$ & $14 \%$ & & \\
\hline \multirow{2}{*}{ All banks ${ }^{d}$} & banks & $8 \%$ & $2 \%$ & $8 \%$ & $1 \%$ & $7 \%$ & $3 \%$ & & \\
\hline & assets & $90 \%$ & $80 \%$ & $84 \%$ & $78 \%$ & $90 \%$ & $85 \%$ & & \\
\hline
\end{tabular}

a Security traded on an exchange and/or easily observable data.

b Expectations of external support; see 4.3.

c Without Clientis, which is an umbrella organization, rather than a bank in the strict sense.

d Big banks consolidated. Percentages slightly biased due to double counting of some subsidiaries of UBS and Credit Suisse Group.

Source: SNB 
banks are grouped within the Raiffeisen Group, which supports its members on various issues including market-based funding. The smallest regional banks are also trying to set up similar 'umbrella organizations'. An example is the Clientis Group, an umbrella organization for about 30 institutions. Up to now, those conglomerates have operated almost exclusively in the traditional bond market and in the Pfandbrief market. Market data would thus become available for aggregate groups of smaller banks, rather than for individual banks themselves.

\subsection{Peculiarities of Available Data and Indicators}

The main problem with debt-based indicators is that few Swiss banks actually borrow on the capital market more than two times per year. Because of this modest borrowing activity, one has to rely on a panel of secondary bond market data for calculating bond spreads. However, in general, the Swiss secondary debt market is relatively illiquid. A big share of debt is purchased by institutional investors, who often hold those securities until maturity. For some bonds (especially those issued by small banks) there may be no trading for several weeks and indicative prices set by the market makers may not be very informative.

Liquidity problems are less pronounced for equity-based indicators. This suggests the estimation of default probabilities by means of the KMV method. Indeed, the calculation of the distance to default for all quoted Swiss banks is relatively unproblematic. Yet, the mapping of the distance to default into a probability of insolvency turns out to be more challenging: The functional form of this relationship is, a priori, unknown and is very difficult to estimate empirically, as the number of bank defaults in Switzerland is extremely small.

Credit and financial strength ratings are of course an additional important source of information on Swiss banks. Unfortunately, only few domestic institutions are currently rated by the principal international agencies. ${ }^{22}$ Yet, demand for information on the solvency of debt issuers is increasing, as bond investors also become more risk sensitive. This may boost the number of banks willing to be rated. Moreover, given that not every debtor can (or wants to) afford a Moody's or S\&P's rating, some banks - e.g. Credit Suisse and the Zürcher Kantonalbank $(\mathrm{ZKB})$ - are publishing rating guides on a larger number of Swiss issuers. One limitation of those handbooks is that their authors do not have access to the confidential records of individual borrowers.

22 Moody's: 9 banks; S\&P's: 12 banks; Fitch: 4 banks (excluding subsidiaries of Swiss bank holding companies and branches of foreign banks). 
Finally, few Swiss banks are treated as reference obligor in CDSs or in other similar transactions. Only for the two big banks are instruments offered, but further research is needed in order to assess the availability and utility of these data.

\subsection{The Role of Explicit or Implicit Guarantees}

The particular structure of the Swiss banking sector may reduce the information content of market prices. First, the two big banks, UBS and CSG, hold assets representing more than 75 percent of aggregate assets of all domestic banks, or almost eight times annual Swiss GDP. Because of their systemic relevance, investors may speculate that the two big banks could be 'too-big-to-fail' (TBTF). If investors believe that a troubled TBTF-bank will always be bailed out by the government, perceived risk will be small and market discipline ineffective. However, looking at the size of UBS and CSG in relation to the domestic economy and the resources of the Swiss public sector, one may wonder if these banks are also 'too-big-to-be-rescued', which would partially offset the distorting effect of the TBTF-problem. ${ }^{23}$ Second, many of the Swiss banks active in financial markets are cantonal banks. These institutions are protected by state guarantee, in some cases only implicitly or to a limited extent, ${ }^{24}$ which may again make market indicators less revealing.

\subsection{Empirical Evidence on Information Quality}

Empirical evidence on the quality of market indicators for Swiss banks or for the whole national financial system is still very limited. BIRCHLER and МАECHLER (2002) find that, in the absence of market prices, quantities of uninsured deposits have predictive power for bank solvency. An empirical analysis of debt spreads (FACCHINETTI, 2007) provides mixed evidence on information quality. Debenture yields react to changes in the risk profile of (non state-owned) banks, but they do not appear to be very valuable to supervisors as early warning indicators. Thus, the market does not appear to have more timely information about

23 At the end of 2004, total assets at UBS amounted to about CHF 2,173 billion, or to almost five times Swiss annual GDP.

24 For the Banque Cantonale Vaudoise (BCV), the guarantee is implicit, while for the Banque Cantonale de Genève (BCGe), there is an explicit guarantee but it is limited. For the other banks the cantons explicitly guarantee all the liabilities except, in some cases, subordinated debt. 
individual institutions than the SFBC. However, this conclusion is based on the (questionable) assumption that the SFBC does not use market information in its supervisory process.

Even by looking at the raw data, however, some interesting facts emerge. First, as already stated, a very good market data set exists for the most systemically important banks, UBS and CSG. Moreover, even if there is some evidence on the presence of a TBTF-effect (RIME, 2005), this bias does not seem to completely destroy the information content of the indicators. Consider for example subordinated bond spreads (see Figure 3): If investors were certain that the two big banks are 'too-big-to-fail', they would not require any return premium for default risk. Yet, in October 2002, CSG bonds traded with an average premium of 240 basis points over a comparable government bond and with a premium of almost 150 basis points over bonds issued by UBS. Such large price discounts would have been arbitraged away in the absence of default risk.

Figure 3: Subordinated Debt Spreads of UBS and Credit Suisse Group

Average over all exchange-traded subordinated bonds satisfying the following conditions: fixed coupons, no options, denominated in Swiss franc, residual term of at least two years. End of month.

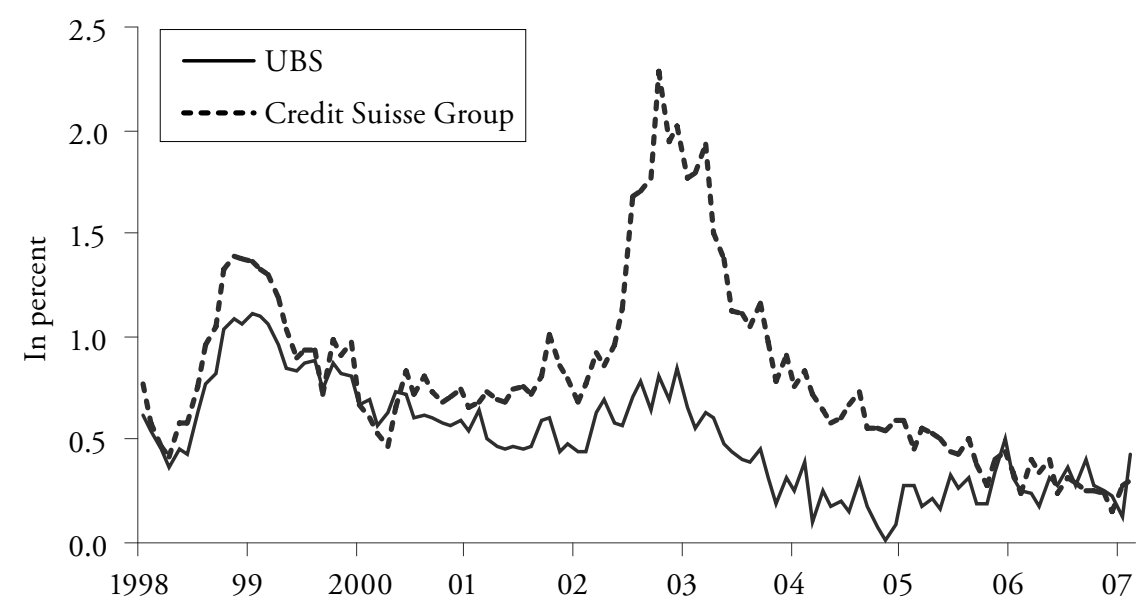

Source: Datastream

On the other hand, the state guarantee appears to limit the usefulness of market indicators for most cantonal banks, as shown by Figures 4 and 5. Only for the Banque Cantonale Vaudoise (BCV) and the Banque Cantonale de Genève 
(BCGe) - the two cantonal banks that do not enjoy a full state guarantee - do yield spreads on senior debt appear to indicate problems. Around 2002, their spread curves exhibit peaks not present in the flat curve for a bank such as the Zürcher Kantonalbank. Unfortunately, the BCV and the BCGe happen to be the only two cantonal banks that have in fact had problems in the period under consideration. Observed spreads thus seem consistent with two interpretations: Either, state guarantee for cantonal banks is discounted by investors, or the limitations of the state guarantee for the two banks are credible, at least to some degree.

Even though the two banks eventually received injections of fresh capital by their respective cantons, we find the latter hypothesis more plausible. First, the $\mathrm{BCV}$ and the BCGe traded with a premium over the other cantonal banks even before the problems became apparent. Secondly, the debt yields of cantonal banks (with the exception of the BCV and the BCGe) move very strongly in tandem. This suggests that, for these borrowers, bond prices are mainly influenced by systematic risk factors and only marginally by the default probabilities of the individual banks. This is also confirmed by empirical analysis (FACCHINETTI, 2007). ${ }^{25}$ There is one final small piece of evidence in favor of investors' confidence in state guarantee (up to the individual canton's financial limits): The Solothurner Kantonalbank, a fully guaranteed cantonal bank with outstanding traded debt failed in 1996 (i.e., prior to the period under consideration). ${ }^{26}$ Within the five years preceding the failure, the bank's senior debt spreads rose from 0.5 percent to only around one percent, thus providing rather faint signals of the bank's weakness.

In the presence of state guarantee, Moody's Bank Financial Strength Ratings or FitchIBCA Individual Ratings, which abstract from potential third party support, could be extremely useful. Unfortunately, among cantonal banks, such a rating is currently available only for the St. Galler Kantonalbank and the Zürcher Kantonalbank (both from Moody's). Another way to lessen the problem of the state guarantee and thereby enhance market discipline would be to limit the scope

25 Evidence on the distorting effects of government guarantees can be also found abroad. FLANNERY and SORESCU (1996) show that US bank investors became risk aware only when the regulator made it clear that they were not protected in the event of default. According to SIRONI (2003), issue spreads on subordinated debt of European public sector banks are, ceteris paribus, less risk-sensitive and about 40 basis points lower than spreads of European private banks. Sironi (2002) and Pop (2006) argue that, due to state guarantees, the average European and Japanese bank bond trades at a lower spread than its North American counterpart.

26 The canton subsidized the takeover of the Solothurner Kantonalbank by SBC, one of the (then three) big banks. 
Figure 4: Senior Debt Spreads of Selected Cantonal Banks

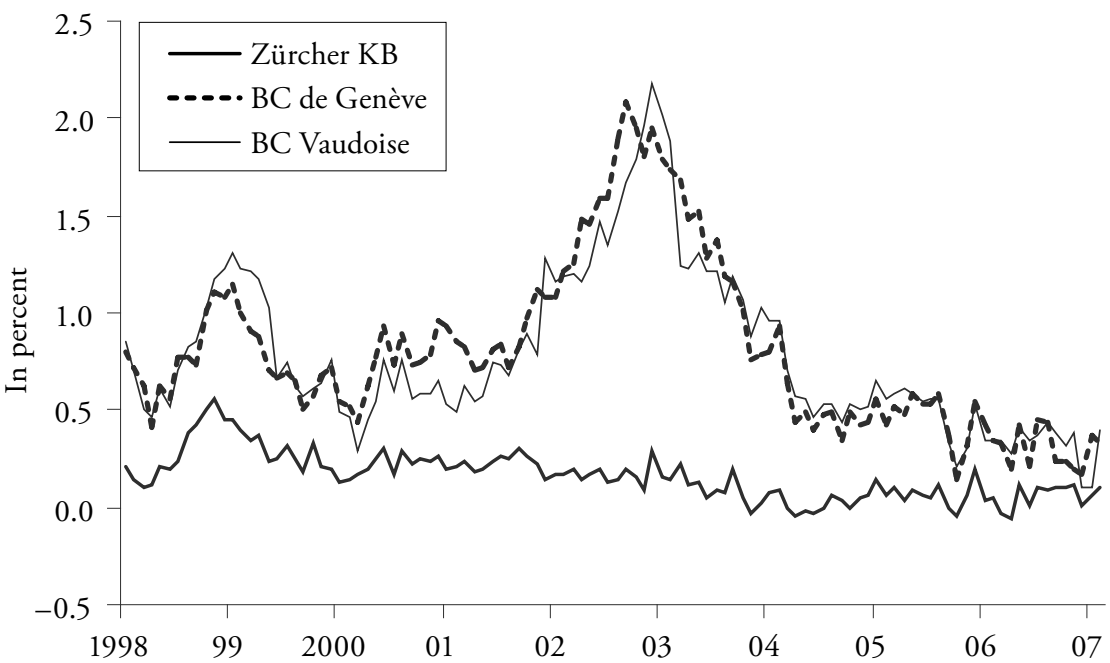

Figure 5: Senior Debt Spreads of Selected Cantonal Banks

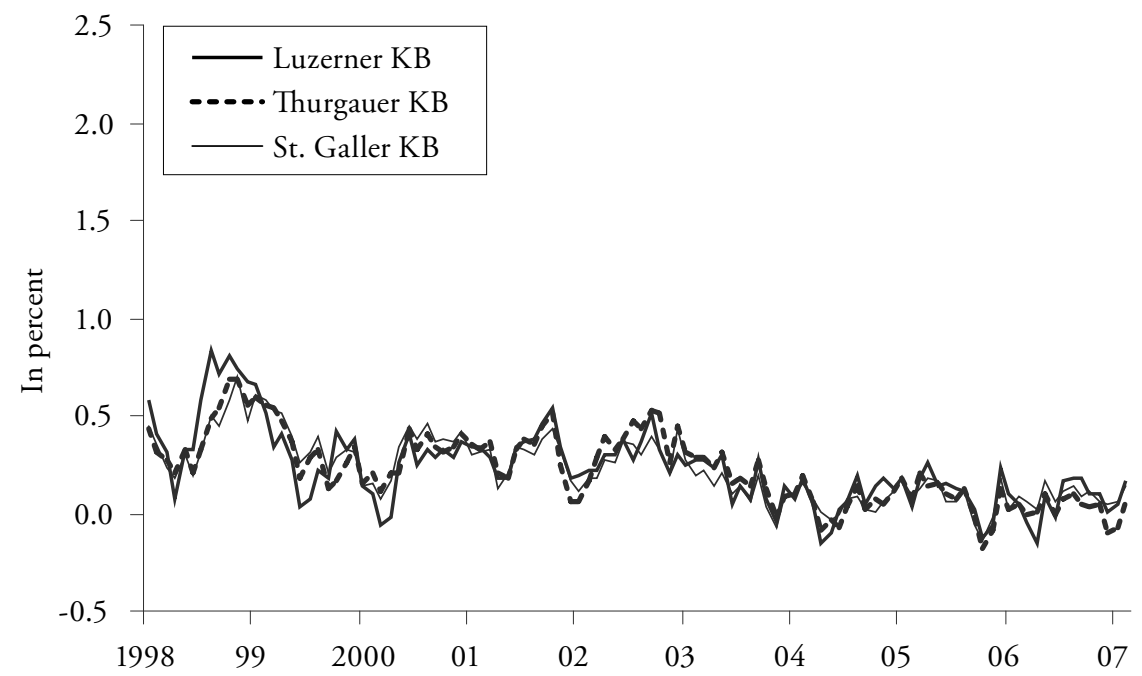

Both Figures: Average over all exchange-traded senior bonds satisfying the following conditions: fixed coupons, no options, denominated in Swiss franc, residual term of at least two years. End of month.

Source: Datastream 
of the protection. At some cantonal banks, ${ }^{27}$ for instance, subordinated debt is currently not guaranteed by the canton. Yet, not surprisingly, only one of these banks has issued publicly traded subordinated securities.

As already stated above, the quality of market data tends to be negatively correlated with bank size. Most small banks have few financial securities outstanding - usually only equity or a few senior bonds - and these securities are barely traded. As illustrated in Figure 6, the bond issued by the Banque Cantonale du Jura (total assets: CHF 2 billion) exhibits almost no price fluctuation five years after issue, an indication that virtually no trading takes place. By contrast, the price of a comparable security issued by the Zürcher Kantonalbank (total assets: CHF 93 billion) changes every few days.

Figure 6: Price Fluctuations of Selected Cantonal Bank Bonds

Daily bond prices (last trade at the SWX exchange).

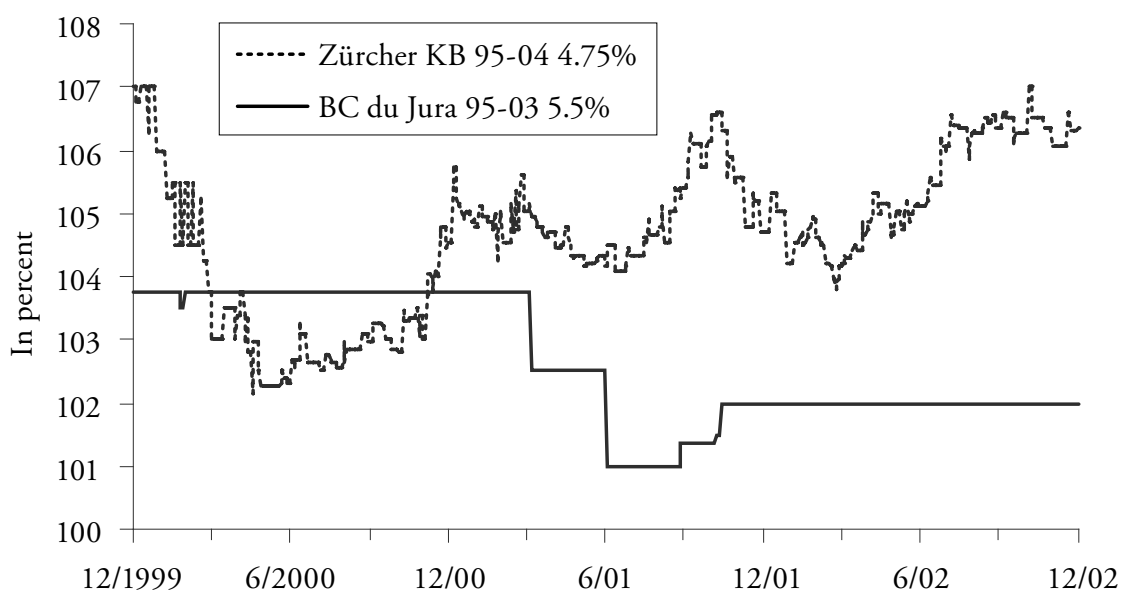

Source: Datastream

Finally, empirical evidence on the Swiss National Bank stress index (Swiss National Bank, 2006, p.44) developed by Hanschel and Monnin (2004, 2005 ) is consistent with the fact that a good set of market data (when combined with non-market data) is available for the Swiss banking system. Indeed, the

27 Glarus, Graubünden, Nidwalden, St. Gallen, Zurich. 
index correctly identifies the four most stressful periods for the Swiss banking system since the 1980s (see Figure 7): (1) the aftermath of the stock market crash in 1987, (2) the consolidation phase following the real estate crisis of the early 1990s, (3) the Russian crisis and the collapse of LTCM (Long Term Capital Management) in 1998, as well as (4) the bursting of the internet bubble after 2000.

Figure 7: The SNB-Stress Index

In standard deviations from the 1987-2006 average.

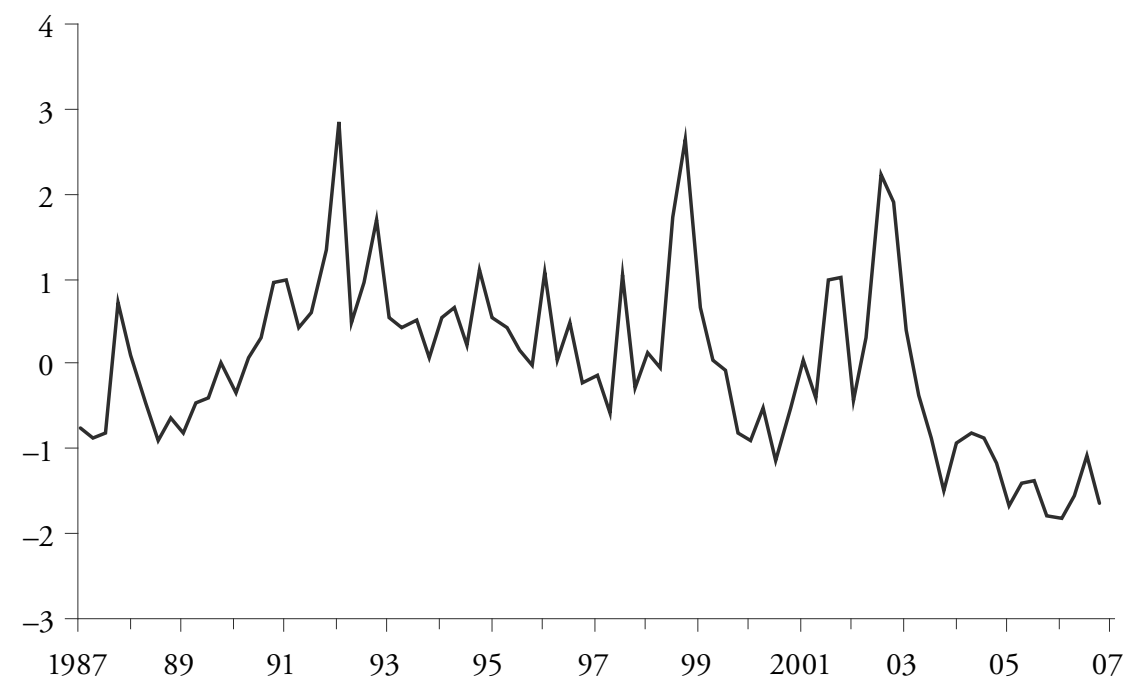

Source: SNB

The information content of market data and other information (including supervisory information) can be assessed from a decomposition of the aggregate stress index into the two components 'Market' and 'Other'. As Figure 8 illustrates, the two sub-indices moved fairly well in parallel during the two most recent periods of stress. In 1991, market data gave an early indicator of the upcoming crises, even though the crisis mainly affected banks without outstanding instruments traded on a regular basis. After the 1987 stock market crash, market data jumped to stress levels without any concomitant deterioration of non-market data. This may look like a false alarm. Yet, the market line may well indicate what would have happened, ceteris paribus, for instance without the reaction by the authorities. 
Indeed, after the stock market crash, the Swiss National Bank's monetary policy was quite expansionary, ${ }^{28}$ which kept systemic stress factors at bay. This may be an example where markets did not anticipate the policy response and thus did not incorporate it in prices (see 2.2 and 5.2.3). By contrast, the 'Market' component of the index largely failed to signal the existence of the internet bubble before it burst in 2000. In this period, prices may have reflected beliefs about (optimistic) beliefs of other investors, rather than economic fundamentals.

Figure 8: The Market and the Non-market Component of the SNB-Stress Index In standard deviations from the 1987-2006 average.

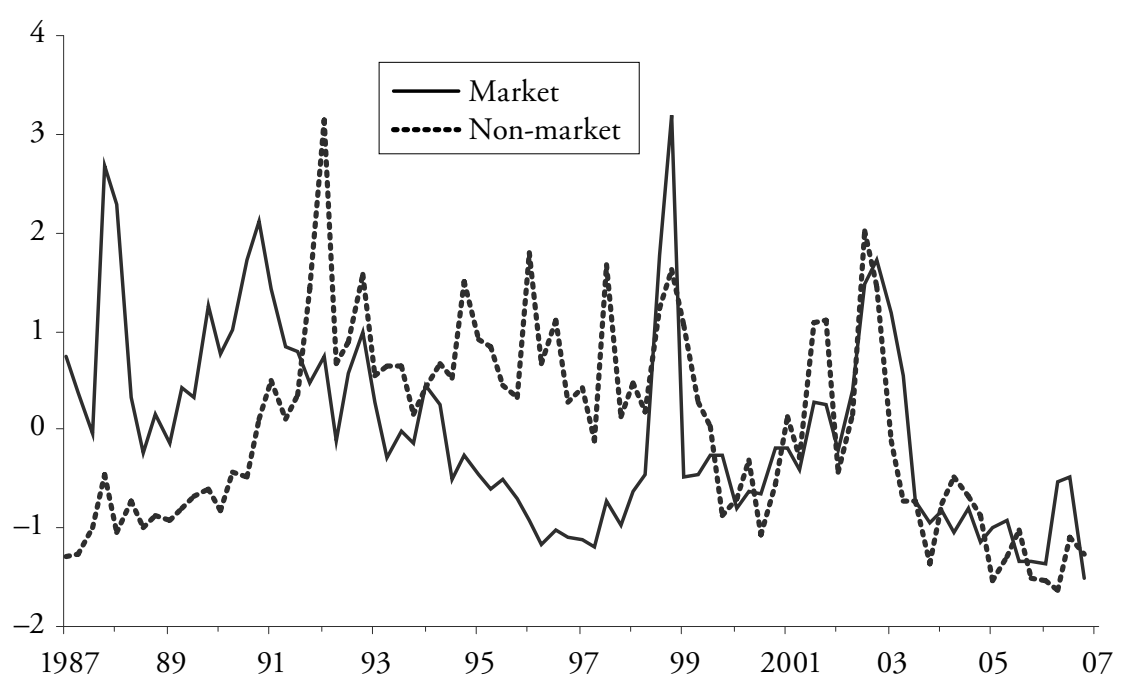

Source: SNB

Figure 8, far from providing an empirical test, is thus an illustration of the complementary character of market and other information as well as their complex relationship. Carefully interpreted, market sensitive measures of systemic pressure, like the SNB stress index, are likely to be superior to measures that do not include any price-based information or include only price-based information.

28 In 1988, three factors contributed to loose monetary policy: (1) the introduction of Swiss Interbank Clearing (SIC), (2) new (lower) cash liquidity requirements for banks, and (3) the SNB's desire to keep interest rates low after the stock market crash. 


\subsection{General Assessment}

Our criteria for data quality are best met by indicators for the big banks. There is a sufficient basket of securities reflecting big banks' risk profiles; these securities are regularly traded in liquid markets, and with the participation of skilled investors. The evidence suggests that market data signal most problems. Potential reservations reflect periods of positive or negative bubbles (when beliefs may occasionally prevail over fundamental facts) and 'too-big-to-fail' expectations which may somewhat distort - but not invalidate - market indicators.

The majority of cantonal banks have fewer debt instruments outstanding, and markets are less liquid. The state guarantee may limit the quality of debt indicators; yet, in the two major recent problem cases (at banks with limited state guarantee) bond spreads did flag the problems.

While market data appear sufficient to give a true picture of financial conditions for a small number of Swiss banks only, these banks actually represent the major part of the banking system. Systemic stability indicators, particularly if they combine market and non-market data, provide valuable information. However, their market component alone may fail to flag problems during stock market bubbles and may give false alarms during downturns.

Empirical evidence from Switzerland - consistent with the evidence from other countries -suggests that, read with some caution, market data contain valuable information on the risk profile of a particular bank or the banking system. Combining supervisory information with market data thus yields a more accurate picture of individual and systemic stability.

\section{The Practical Use of Market Data by Bank Supervisors}

Supervision, as a practical exercise, is oriented towards action. The question thus arises: What should supervisors do with information provided by the market? In what follows, we highlight some issues that arise when supervisors use market data for policy intervention.

\subsection{Defining a Role for Market Data}

An agency intending to use market information in an active way is confronted with the question: What is the optimal link between market data and policy action? Generally speaking, such an 'intervention function' $F$ can be written as: 


$$
\mathbf{I}=F(\mathbf{M}, \mathbf{P}, \mathbf{S}, d)
$$

where I denotes the vector of actions taken by the agency as a function of a vector of market data $\mathrm{M}$, a vector of other public information like accounting data $\mathrm{P}$, a vector of private supervisory information $S$, and a discretionary term, $d$. Market data, M, and other public information, $\mathbf{P}$, are publicly observable. Supervisory information, $\mathrm{S}$, is not publicly observable. The discretionary term $d$ cannot be specified in advance. It stands as a residual summing up all unforeseen influences to which the agency could react.

The intervention function thus specifies how market and other information interact in supervisory decisions, as well as the degree of supervisory discretion. Two examples may illustrate the range of possibilities. The 'Calomiris proposal' (Calomiris, 1999) stands for the rule-oriented end of the spectrum. In its simplest form, it aims at an intervention function that has only $\mathbf{M}$ as an argument. Indeed, $\mathbf{M}$ would have only one element: the subordinated debt spread. Were this spread to hit a threshold, it would trigger the closure of the respective bank. The 'action space' would thus have two elements only: laissez-faire and closure.

The other example, marking the discretion-based end of the spectrum, is the Greenspan suggestion (Greenspan, 2001) quoted above. It simply states that significant changes in a banking organization's debt spreads could prompt more intensive monitoring. It has a role for all information: market, public non-market, and supervisory. Apart from more intense monitoring, no action is specified, thus allowing almost full discretion. More intensive monitoring may not even be read as an action, but rather as an attempt to improve the quality of supervisory information, i.e., of one of the arguments in the intervention function.

Between the Calomiris proposal and the Greenspan suggestion there is a whole range of possibilities. At present, most authorities in industrial countries use market prices cautiously and with a lot of discretion (see footnote 6). However, some agencies may apply some explicit rules in selected areas. The following examples illustrate some possibilities; they are not intended to be either exhaustive or normative:

- Special audits or management reports to a supervisor could become due automatically if the share price based distance to default falls below a given limit.

- Under the second pillar (national implementation) of 'Basel II', a national authority, for instance, could require an add-on to a bank's regulatory capital or an equity issue, if the bank's debt spread exceeds given thresholds. 
- A central bank, as part of its function as lender of last resort could react to a deterioration in a bank's market data in two ways: It could initiate preparatory measures and/or it could become more cautious in lending decisions and collateral valuation.

- Deposit insurance premiums could be tied to market data.

These are examples of potential ways in which market indicators could be integrated within a supervisory framework. They are listed here for the purpose of illustration. Any attempt to weigh the benefits of the individual options against their drawbacks is beyond the scope of this paper. There are, however, critical issues in the practical use of market data, irrespective of individual options. Supervisors who use market data as a basis for action should be aware of the following limitations and problems.

\subsection{The Limitations of Market Prices as Policy Guides}

\subsubsection{Prices Do not Provide Reasons}

As mentioned in 2.2, market efficiency means that prices reflect all available information. However, it does not imply, that prices reveal that information. As Hayek put it, the market is useful precisely because market participants do not need to know why a good or a security has become more or less valuable, but only by how much.

Revealing prices would mean that we could work back from observed prices to all the information that went into prices. In theory, such reverse engineering is possible under strong assumptions; in practice it is not. ${ }^{29}$ Consequently, supervisors cannot read from an increase in a bank's debt spread whether the management is bad or the credit portfolio weak, whether there is fraud in a trading room or an imminent international debt crisis that would hit this particular bank. Such information might be important, however, for locating the problem and choosing the right supervisory intervention.

One way to mitigate the problem would be to interpret bank specific market prices in the light of other market information. Such information includes interviews with market participants or bank credit ratings. Note that, unlike the price mechanism, rating agencies usually do outline the 'why', i.e., the rationale behind each rating action.

29 For the conditions under which, theoretically, prices reveal the underlying information see Brunnermeier (2001, p. 25). 


\subsubsection{Markets Do not Price Policy Alternatives}

A related point is that, by their very nature, market data cannot tell the supervisor 'what to' do (again, ratings may be an exception since they clarify the source of a problem). At any point in time, there is only one set of market prices. These reflect what average market opinion expects to happen. There are no alternative sets of market prices that reflect optional worlds. Thus, at best, the price system provides supervisors with a snapshot picture of market expectations, but it cannot be used as a flight simulator showing the impact of alternative policy decisions.

While market prices may flag the existence of a problem, they say little about its cause and nothing about what could be done. If an increase in a bank's debt spreads should lead to a "more intensive monitoring of the institution" (GreENSPAN, 2001), it remains to be explored how such monitoring could obtain any further guidance from market data.

\subsubsection{The Endogeneity Problem}

Some further complications arise from the fact that market prices do not reflect economic reality net of supervisory action. Like any other event, expected supervisory or governmental actions are included in prices if markets are efficient. Prices thus are endogenous to supervisory actions. A nice empirical example is documented by DeYoung, Flannery, Lang and Sorescu (2001): The authors find that bond spreads of financially troubled banks tend to decrease after an unexpectedly poor outcome of an on-site examination. They argue that, after a bad examination, markets anticipate a tougher supervisory stance. The authors conclude that "the anticipated regulatory response frequently dominates the information's implications about current bank conditions" (p. 902). This effect has not really been highlighted by the advocates of using market prices for supervision; in the context of currency crises it is briefly mentioned by SHIN (2002).

In the other direction, supervisors may, in the spirit of the present section, react to prices. Some economists have even proposed an explicit and mechanical link between market data and supervisory action (see, for instance, CAlomiris, 1999). While we do not deny the potential merits of such proposals, we would like to highlight one particular problem: When actions become endogenous to prices, the connection between prices and actions may become fully circular: Prices reflect rationally expected actions and, at the same time, also trigger those very actions.

From a supervisory perspective, we can call this potential circularity of prices and actions the endogeneity dilemma. Supervisors face a dilemma, as the active use of market prices for supervisory action may in fact destroy their informational 
content by preventing the existence of an equilibrium (see box below, Example 1). It might seem that the endogeneity dilemma is the end to the idea of market data based supervisory action. However, this is not the case. There are two factors, one theoretical and one practical, that serve to 'soften' the endogeneity dilemma.

\section{Example 1: A Potential Paradox}

In the following example, the two-way endogeneity of prices and supervisory actions destroys the information content of market prices.

The supervisory authority announces a subordinated debt policy. Under this policy, a bank is obliged to issue equity once the yield spread on its subordinated debt hits 3 percent. This policy is both credible and common knowledge. ${ }^{30}$

If the bank is always successful in raising the required capital, subordinated debt holders can never lose any money. Knowing this, they would never sell their debt at the discount implied by a 3 percent yield spread. The spread thus would never rise to 3 percent in the first place, and the supervisor would never require the equity issue! But, if supervisors never intervene the spread should hit the 3 percent threshold, forcing the supervisor to intervene. Thus neither intervention nor non-intervention are equilibrium strategies.

\section{Example 2: An Equilibrium Outcome}

In the following example the supervisor has an equilibrium strategy, even though prices and actions mutually depend on each other.

The supervisor, who only intervenes at discrete intervals (once a year, say) requires recapitalization whenever a bank's spread is found to exceed 3 percent. There is an equal probability of either recapitalization succeeding and bringing the spread down to the 3 percent threshold, or failing, leaving the spread unchanged. Again, all of this is common knowledge.

Assume a bank has an insolvency risk that would require a spread of 5 percent. The supervisor thus would intervene and require that the bank recapitalize. Success and failure being equally likely, the equilibrium spread would be the mean between 3 percent (success) and 5 percent (failure). There is thus an equilibrium at a spread of 4 percent. Note, however, that in this example the equilibrium only exists because the intervention of the supervisor is not always successful. ${ }^{31}$

The theoretical reason is that an equilibrium price may still exist, even if supervisors tie their actions to market prices. We present an example in which the presence of a random element supports an equilibrium (see box above, Example 2).

30 A policy is common knowledge if everybody knows that policy, everybody knows that everybody knows that policy, everybody knows that everybody knows that everybody knows that policy, and so on ad infinitum.

31 Note also, that prices remain informative despite the endogeneity dilemma. Observing a spread of 4 percent, with the commonly known success probability of 50 percent, a supervisor can infer that in the absence of intervention a spread of 5 percent would be required. 
The practical way around the endogeneity problem is to adopt an appropriate design for both bank securities and supervisory interventions. The problem arises because the prices of bank securities respond to supervisory interventions (and may, in turn, serve as a trigger for these interventions). To eliminate the problem, the supervisor needs to find a bank security that is sensitive to the bank's condition, but not sensitive to supervisory intervention. Typical candidates are shares or subordinated debt. If supervisors can save a troubled bank without bailing out shareholders or the holders of subordinated debt, the prices of these securities will provide an undistorted picture of the bank's true condition. Consequently, the endogeneity paradox does not arise, even if intervention is triggered by movements in share prices or by an increase in the subordinated debt spread. Generally speaking, asset prices remain informative if the supervisor is known (and able) to intervene in a manner that allocates the losses a bank has already incurred to the holders of the individual assets. Supervisory intervention is then 'price neutral' as far as these assets are concerned.

Although Swiss supervisors do not tie actions to security prices, the endogeneity problem has been serious for a number of banks, at least in the past. With the state guarantee for cantonal banks and 'too-big-to-fail' expectations, prices for bank debt often reflected policy responses (government bailout) rather than bank risk profiles. Prospects for intervening without any impact on prices are somewhat better under the new bank insolvency regulations (section 11, Swiss Banking Act; effective July 1, 2004). The SFBC, in the course of a mandatory restructuring, has the right to cut into the claims of the holders of equity, subordinated debt or other unsecured (third-class) debt. As far as Swiss law applies, rescuing a bank as an ongoing concern thus does not imply a bailout of shareholders and creditors. These are at risk, even if a bank is rescued. This safeguards the information content of market prices for equity and debt and permits their use as risk indicators or even as triggers for supervisory action. However, the problem will remain for the great majority of cantonal banks that only issue securities protected by state guarantee.

\subsubsection{The Pressure of Market Data}

A final important characteristic of market data is that they are publicly observable. Present and past stock prices, for instance, can be checked by anybody, either in the newspaper or on the website of a stock exchange; credit derivative prices are available from specialized suppliers of financial data like Bloomberg. Even if hardly anybody reads all the prices all the time, they are, in principle, available to any interested party. Market data thus are common knowledge. 
The public nature of market data creates an incentive for supervisors to 'do something' after significant movements in such prices. It seems reasonable to assume that a supervisory authority, even if independent, is in some form penalized, if (i) a bank fails, and (ii) there is sufficient evidence that the existence of a problem was known to the authority ahead of the failure. The penalty may include public criticism, loss of independence, changes in management or even lawsuits and fines. ${ }^{32}$ Publicly observable market data, an increase in a bank's debt spread, for instance, may be regarded as evidence that the authority knew or should have known that a problem existed. A supervisory authority thus runs a higher risk of being penalized for delayed intervention in the case of a bank that has outstanding traded instruments than it would in the case of a bank for which no market information exists.

This may have beneficial or adverse effects. If a supervisory agency strongly dislikes intervention, the pressure of market prices is likely to be beneficial. As a source of supervisory discipline, this counteracts the tendency towards regulatory forbearance.

If, however, a supervisory agency has no bias towards forbearance, market price pressure is likely to go too far. It is well-known that the common knowledge character of public information may distort decisions (MORRIS and SHIN, 2002): Public information is given an excessive weight, as compared to private information. Supervisors fearing allegations of forbearance have an incentive to react to price movements, even though they regard these as non-informative. In this case, the existence of market prices will reduce rather than improve the quality of supervisory decisions.

Over time, the latter effect - pressure for excessive intervention - is likely to become more important, especially in those countries with a strong tendency for prompt corrective action. More and more securities or contracts sensitive to the condition of banks are traded. Markets are increasingly used as forecasting devices in many areas. Public awareness of market data on bank solvency is thus likely to increase. This may create pressure on the authorities to 'do something' when market prices flag a potential problem at a bank, even in situations when supervisory information clearly suggests that the bank is sound.

32 For instance, the governments of the cantons Vaud and Geneva sued the SFBC in relation to the huge losses incurred by their cantonal banks, arguing that the Swiss supervisor did not properly supervise the two institutions. The Bank of England faced a similar suit - which was dropped in 2005 - by representatives of BCCI (Bank of Credit and Commerce International), a bank that failed in 1991. 


\section{Conclusions on the Use of Market Data by Financial Authorities}

The above analysis leads to a number of conclusions. Regarding the information content of market prices we find that:

- Market data are an important source of information on individual banks' financial health and on financial stability, for both the supervisory authority and the lender of last resort. Market information and supervisory information are complementary: Market prices often represent information not yet known to supervisors. At the same time, confidential supervisory information is not always reflected in market prices.

- Market data cannot provide supervisory authorities with all the information they would find useful. Market data give some indication of expected losses or the probability of failure. However, they say little about the potential causes of an observed increase in the probability of failure, and even less about the appropriate cure.

- Market data never reflect economic fundamentals per se. They rather tend to reflect investor beliefs about fundamentals or, in some episodes, beliefs about other market participants' beliefs. Thus, market prices may not always reflect investors' true perceptions of the probability of a bank failure.

- Economists have not yet explored the functional association of various solvency and risk indicators in any great detail. Given the complementary role of individual indicators and their respective advantages and drawbacks, a better understanding of their joint information content would be highly desirable.

- The information content of market prices is endogenous, i.e., it depends on their supervisory use. Market prices reflect a bank's condition after expected supervisory intervention. Prices for bank debt and equity are thus most informative if supervisory actions do not exonerate the holders of such assets from losses that the bank incurred prior to supervisory intervention.

- The public nature of market data may create some pressure for the supervisory authority to react. Supervisors may thus tend to give market information more weight than they believe would be appropriate.

Regarding the future use of market prices by the Swiss authorities we find that:

- Market data exist for a minority of Swiss banks, but for a major share of the banking system. The best data exist for the two big banks, which are pivotal for the functioning and stability of the system.

- In Switzerland, except for the big banks, supervisory data collected directly from the banks or in the course of on-site examinations traditionally play a 
minor role, as compared to auditors' reports. Market information on cantonal banks, the second most relevant domestic banking group, and a number of other relatively important banks is thus potentially valuable for the bank supervisor, the SFBC. Unfortunately, data on cantonal banks are partially distorted by state guarantee.

- Market prices send valuable signals to other authorities, like the SNB, which does not have direct access to all confidential information available to the SFBC.

- As in the past, in the foreseeable future the Swiss authorities are likely to use market information as a complement to other sources of intelligence. Such use may even be explicit, as in the case of the SNB systemic stress index. However, we do not expect an explicit use of market data for rule-based supervisory intervention.

Given the increasing complexity of large internationally active banks, we expect that financial authorities and other observers will become more and more interested in market data. Market information is a promising source of supervisory intelligence and a potential basis for supervisory action. At the same time, the special informational characteristics of market data, their endogeneity in particular, hint at some potential pitfalls with respect to their unreflected use. Hence, for supervisors, market information is a bit like an oracle: It offers valuable insights to the careful listener, but leads the rash interpreter astray. We hope that further research and practical experience will clarify some of the outstanding issues.

\section{References}

Bank for International Settlements (2006), BIS Quarterly Review, June. Basel Committee for Banking Supervision (2000), "Credit Ratings and Complementary Sources of Credit Quality Information”, Working Paper No. 3, August.

Basel Committee for Banking Supervision (2003), "Markets for Bank Subordinated Debt and Equity in Basel Committee Member Countries", Working Paper No. 12, August.

Basel Committee for Banking Supervision (2005), "Basel II: International Convergence of Capital Measurement and Capital Standards: A Revised Framework", November.

Berger, Allen N., Sally M. Davies and Mark J. Flannery (2000), "Comparing Market and Supervisory Assessments of Bank Performance: Who Knows What When?", Journal of Money, Credit, and Banking, 32 (3), pp. 641-667. 
Birchler, Urs W. and Diana Hancock (2003), "What Does the Yield on Subordinated Bank Debt Measure?”, Working Paper 2004-2, Swiss National Bank.

Birchler, Urs W. and Andrea M. Maechler (2002), "Is there Market Discipline in Swiss Banks?", in: George G. Kaufman (ed.), Research in Financial Services, Prompt Corrective Action in Banking: 10 Years Later, Volume 14, pp. 243-257.

Board of Governors of the Federal Reserve System (1999), "Using Subordinated Debt as an Instrument of Market Discipline", Staff Study 172.

Bongini, Paola, Luc Laeven and Giovanni Majnoni (2002), "How Good is the Market at Assessing Bank Fragility? A Horse Race between Different Indicators", Journal of Banking \& Finance, 26 (5), pp. 1011-1028.

Brewer, Eliah III, Hesna Genay, William Curt Hunter and George G. Kaufman (2003), "Does the Japanese Stock Market Price Bank-Risk? Evidence from Financial Firm Failures", Journal of Money, Credit, and Banking, 35 (4), pp. 507-543.

Brunnermeier, Markus M. (2001), Asset Pricing under Asymmetric Information, Oxford, UK.

Calomiris, Charles W. (1999), "Building an Incentive-Compatible Safety Net", Journal of Banking \& Finance, 23 (10), pp. 1499-1519.

Cannata, Francesco and Mario Quagliarello (2005), "The Value of Market Information in Banking Supervision: Evidence from Italy", Journal of Financial Services Research, 27 (2), pp. 139-162.

Crosbie, Peter J. and Jeffrey R. Bohn (2002), "Modeling Default Risk”, KMV LLC.

Curry, Timothy, Peter J. Elmer and Gary S. Fissel (2003), "Using Market Information to Help Identify Distressed Institutions: A Regulatory Perspective", FDIC Banking Review, 15 (3), pp. 1-16.

Demirgüç-Kunt, Asli and Harry Huizinga (2004), "Market Discipline and Deposit Insurance", Journal of Monetary Economics, 51 (2), pp. 375-399.

Dewatripont, Mathias and Jean Tirole (1994), The Prudential Regulation of Banks, Cambridge, MA.

DeYoung, Robert, Mark J. Flannery, William W. Lang and Sorin M. Sorescu (2001), "The Information Content of Bank Exam Ratings and Subordinated Debt Prices", Journal of Money, Credit, and Banking, 33 (4), pp. 900-925.

Elton, Edwin J., Martin J. Gruber, Deepak Agrawal and Christopher Mann (2001), "Explaining the Rate Spread on Corporate Bonds", Journal of Finance, 56 (1), pp. 247-277. 
Evanoff, Douglas D. and Larry D. Wall (2001), "SND Yield Spreads as Bank Risk Measures”, Journal of Financial Services Research, 20 (2/3), pp. 121-146.

Evanoff, Douglas D. and Larry D. Wall (2002), "Measures of Riskiness of Banking Organizations: Subordinated Debt Yields, Risk-Based Capital, and Examination Ratings", Journal of Banking \& Finance, 26 (5), pp. 989-1009.

Facchinetti, Matteo (2007), "The Prospects of Market Discipline for Banks. Evidence from the Swiss Bond Market", mimeo.

Fan, Rong, Joseph G. Haubrich, Peter Ritchken and James B. Thomson (2003), "Getting the Most out of a Mandatory Subordinated Debt Requirement", Journal of Financial Services Research, 24 (2/3), pp. 149-179.

Flannery, Mark J (1998), "Using Market Information in Prudential Bank Supervision: A Review of the U.S. Empirical Evidence", Journal of Money, Credit, and Banking, 30 (3), pp. 273-305.

Flannery, Mark J. and Sorin M. Sorescu (1996), "Evidence of Bank Market Discipline in Subordinated Debenture Yields: 1983-1991", Journal of Finance, 51 (4), pp. 1347-1377.

Greenspan, Alan (2001), "Harnessing Market Discipline", The Region: Banking and Policy Issues Magazine, Federal Reserve Bank of Minneapolis, September.

Gropp, Reint, Jukka Vesala and Giuseppe Vulpes (2006): "Equity and Bond Market Signals as Leading Indicators of Bank Fragility", Journal of Money, Credit, and Banking, 38 (2), pp.399-428.

Gropp, Reint, Marco lo Duca and Jukka Vesala (2006), "Bank Contagion in Europe", ECB Working Paper No. 662, European Central Bank.

Gunther, Jefferi W., Mark E. Levonian and Robert R. Moore (2001), "Can the Stock Market Tell Bank Supervisors Anything They Don't Already Know?", Federal Reserve Bank of Dallas Economic and Financial Review (2nd Quarter), pp.2-9.

Hancock, Diana and Myron L. Kwast (2001), "Using Subordinated Debt to Monitor Bank Holding Companies: Is It Feasible?”, Journal of Financial Services Research, 19 (2/3), pp. 147-187.

Hanschel, Elke K. and Pierre Monnin (2004), "Measuring and Forecasting Stress in the Banking Sector. Evidence from Switzerland", mimeo.

Hanschel, Elke K. and Pierre Monnin (2005), "Measuring and Forecasting Stress in the Banking Sector: Evidence from Switzerland", in: Investigating the relationship between the financial and real economy, BIS Papers No. 22, April.

Hayek, Friedrich A. (1945), "The Use of Knowledge in Society", American Economic Review, 35 (4), pp. 519-530. 
Illing, Mark and Ying Liu (2003), "An Index of Financial Stress for Canada", Working Paper 2003-14, Bank of Canada.

Krainer, John, and Jose A. Lopez (2001), "Incorporating Equity Market Information into Supervisory Monitoring Models", Journal of Money, Credit, and Banking, 36 (6), pp. 1043-1067.

Lengwiler, Yvan (2004), Microfoundations of Financial Assets: An Introduction to General Equilibrium Asset Pricing, Princeton, NJ and Oxford, UK.

Merton, Robert C. (1974), "On the Pricing of Corporate Debt: The Risk Structure of Interest Rates”, Journal of Finance, 29 (2), pp. 449-470.

Morris, Stephen and Hyun Song Shin (2002), "The Social Value of Public Information”, American Economic Review, 92 (5), pp. 1521-1534.

O'Hara, Maureen (1995), Market Microstructure Theory, Cambridge, MA.

Persson, Mattias (2002), "Stock Market Indicators of Bank Fragility - Evidence from the Nordic Banking Crisis", Working Paper, Sveriges Riksbank.

Pop, Adrian (2006): "Market Discipline in International Banking Regulation: Keeping the Playing Field Level", Journal of Financial Stability, 2 (3), pp. 286-310.

Rhode, Paul W. and Koleman S. Strumpf (2004), "Historical Presidential Betting Markets”, Journal of Economic Perspectives, 18 (2), pp. 127-142.

Rime, Bertrand (2005), "Too Big to Fail”, The Financial Regulator, 10 (3), pp. 46-51.

Shiller, Robert J. (2000), Irrational Exuberance, Princeton, NJ.

Shin, Hyun Song (2002), Comments on "How Good Is the Market at Assessing Bank Fragility? A Horse Race between Different Indicators", Journal of Banking \& Finance 26 (5), pp. 1029-1031.

Shleifer, Andrew (2000), Inefficient Markets: An Introduction to Behavioral Finance, Oxford, UK.

Sironi, Andrea (2001), "An Analysis of European Banks Subordinated Debt Issues and Its Implications for a Mandatory Subordinated Debt Policy", Journal of Financial Services Research, 20 (2/3), pp. 233-266.

Sironi, Andrea (2002), "Strengthening Banks' Market Discipline and Leveling the Playing Field: Are the Two Compatible?”, Journal of Banking \& Finance, 26 (5), pp. 1065-1091.

Sironi, Andrea (2003), "Testing for Market Discipline in the European Banking Industry: Evidence from Subordinated Debt Issues", Journal of Money, Credit, and Banking, 35 (3), pp.443-472.

Swidler, Steve and James A. Wilcox (2002), "Information about Bank Risk in Options Prices”, Journal of Banking \& Finance, 26 (5), pp. 1033-1057.

Swiss National Bank (2006), Financial Stability Report. 
Sy, Amadou N.R. (2002), "Emerging Market Bond Spreads and Sovereign Credit Ratings: Reconciling Market Views with Economic Fundamentals", Emerging Markets Review, 3 (4), pp.380-408.

Wolfers, Justin and Eric Zitzewitz (2004), "Prediction Markets", Journal of Economic Perspectives, 18 (2), pp. 107-126.

\section{SUMMARY}

Market data, such as bond spreads or equity price volatility, are a complementary source to bank supervisory information. In Switzerland, meaningful market data are available for a number of banks which constitute a major part of the banking system. Notwithstanding some limitations (biases due to state guarantee for cantonal banks and potential 'too-big-to-fail' expectations for big banks) these market data are likely to play a supervisory role in the future. However, once the market expects supervisors to react to market data, these data become endogenous. This may jeopardize the very potential of market data to serve as policy guides. 